ERIC S. NELSON

\title{
INTRODUCTION: \\ INTERSECTIONS BETWEEN CHINESE AND WESTERN PHILOSOPHIES
}

\section{A Question of Interpretation}

The articles gathered in this supplementary issue of the Journal of Chinese Philosophy provide an opportunity for exploring several interpretive intersections, encounters, and divergences between Western, primarily modern European, and classical Chinese philosophies. This collection brings together five newly written articles and four articles, some of which have been revised, from past issues of the journal. These contributions taken as a whole directly and indirectly raise anew questions of whether there is such a thing as "Chinese philosophy," a possibility that is denied by prevalent trends in Western philosophy from the Enlightenment and romanticism to contemporary ahistorical universalisms and postmodern occidental particularisms, and whether philosophy should be understood as one unified monistic form of thought or as a more diverse and inclusive plurality of philosophies.

To speak of philosophies, instead of philosophy, might risk sounding peculiar to ears trained and habituated to thinking of philosophy as either one universal theoretical truth or as one particular historical and fateful transmission from the Greeks to their self-declared modern occidental inheritors. Yet if, as the hermeneutical lifephilosopher Georg Misch argued in the 1920s, the unity of philosophy does not consist in the identity of one theoretical vision or one historical tradition, then its universality need not entail the negation of the particularities through which it occurs and is enacted. ${ }^{1}$ Philosophy only has its living actuality in the concrete moments in which, according to Misch, there is an existential encounter, crisis, or breakthrough (durchbruch) that leads to critical reflection on life and its conditions and to personal and social transformation. These concrete moments of disorientation and reorientation—of breakthrough, reflection, and

ERIC S. NELSON, Associate Professor, Department of Philosophy, University of Massachusetts Lowell. Specialties: Chinese philosophy, comparative philosophy, European philosophy. E-mail: eric_nelson@uml.edu

Journal of Chinese Philosophy, Supplement to Volume 39 (2012) 5-9

(C) 2013 Journal of Chinese Philosophy 
transformation-occurred in diverse forms in China, India, Israel, Persia, and so on, as well as in ancient Greece and the modern Enlightenment that have a unique historical significance for Western civilization.

Philosophy and its overcoming in meditative mindfulness (Besinnung) only happens for the few and the rare for a thinker such as Heidegger. ${ }^{2}$ But an earlier hermeneutical conception of reflective mindfulness (Besinnung), one articulated in the writings of Misch and his teacher and father-in-law Wilhelm Dilthey, suggests that critical reflection is a constant possibility of the social and individual selfreflexivity of everyday human life. ${ }^{3}$ Philosophy is not an impersonal event of being; it is a deeply personal encounter with the internal and external conditions of one's life.

As such, philosophizing can happen anew each time such a moment occurs. This encounter is indicated in the Chinese expression "I understand" (wo zhi 我执). Like another thinker influenced by Dilthey, Martin Buber, Misch was particularly taken by the figure of Zhuangzi 莊子. Misch's first example of such a disorienting breakthrough and reorienting life-reflection is the great river's shock and surprise when it encountered the sea. In “Autumn Floods" (Qiushui〈秋水〉) in the Zhuangzi 《莊子》, the river egotistically delighted in its own power and greatness, which absorbed all the streams and channels that flowed into it, until it was exposed to the limitless expanse of the northern ocean. ${ }^{4}$ The "breakthrough" of the world in the self does not occur through any particular content; it is noticeable in the Buddha's reorienting exposure to the suffering of others or in the dialogical endeavors of Mengzi 孟子 to awaken King Hui of Liang (Liang Hui Wang 梁惠王) to his responsibility. The occurrence of breakthrough, reflection, and potential transformation occurs in the midst of the context of biological-historical life. It need not presuppose one universal philosophical doctrine, a hidden metaphysical reality beyond the conditions of the nexus of life, or the myth of one coherent and continuous metaphysical tradition stemming from Hellas and culminating in Western modernity.

In contrast to the frequent exclusion of Kongzi 孔子 from the philosophical canon by Western thinkers, Misch remarked that Socrates could not be considered a philosopher either if the same criteria were consistently applied; for example, dialogical and indirect teaching instead of an explicit systematic theoretical discourse, reflecting on ethical life rather than speculation about nature or the supernatural, and the immanent hermeneutical enlightening of historical life to itself in conjunction with individual self-cultivation (Bildung) in contrast with the impersonal and neutral external or transcendent point of view favored by modern Western philosophy. ${ }^{5}$ 
Given Misch's pluralizing and individuating hermeneutical understanding of philosophies as a singular plural point of departure, works discussed in the essays collected here-such as the Yijing 《易經》, the Daodejing 《道德經》, and the Zhuangzi-can emerge as philosophically worthwhile texts that can be considered in their own right without requiring that they conform to restrictive conceptions of what counts as philosophy and non-philosophy. Once textual sources are explored and explicated responsively from out of themselves in their own terms, then genuine interpretive encounters and intersections can take place and be articulated between texts of diverse provenance without assuming either a common identity or their incommensurability. Such a pluralistic hermeneutics leaves open and undecided the difficult questions of philosophy about nature, religion, and morality that have been posed, answered, and posed anew.

\section{AndEnKEN}

In this context of engaging in intercultural and comparative philosophy, it is fitting to recall the life of a scholar and teacher whose works concerned German hermeneutics and life-philosophy, intercultural East-West philosophy, Japanese and global feminism, and a critical encounter with and reflection on the conditions of life of women in modern Japan and Asia. I am thankful that she encouraged me-as a graduate student writing a dissertation about history in Dilthey and Heidegger in the late 1990s - to expand my philosophical horizon beyond Europe. I wish to devote this moment to remembering a dedicated scholar, encouraging mentor, and a generous friend, Sakiko Kitagawa 北川 東子 (1952-2011). Because of her role in facilitating the encounter and dialogue between East Asian and European philosophy, she had been invited to contribute to this issue. After years of fighting against her illness, she passed away too early, and will be sorely missed by myself, her family, friends, and colleagues, and as a contributor to this special collection.

\section{INTERPRETIVE INTERSECTIONS}

A number of essays engage the divide and intersection between Chinese and Western philosophies by focusing on the classic Daoist texts of the Daodejing and the Zhuangzi in relation to twentiethcentury Western thought. Chung-ying Cheng discusses in his article the affinities and differences between deconstruction and différance staged in the writings of Jacques Derrida and the movement of the 
dao 道 through reversal, return, and emergence in the Daodejing in order to offer a Daoist onto-hermeneutical reinterpretation of and critical response to Derrida. Tao Jiang reexamines in his essay Zhuangzi's soteriological project of personal liberation in light of Isaiah Berlin's distinction between positive and negative freedom. The liberal notion of negative freedom limiting state power correlates with and corrects the deeply personal yet apolitical meditation on freedom exhibited in the Zhuangzi. Lin Ma considers why the feminine articulated in Levinas's early work loses its importance in his later thought from an intercultural perspective. She reassesses Levinas's at times problematic thinking of the feminine with respect to the feminine, for example, the water metaphor and $c i$ 雌, expressed in the Daodejing.

Three essays redeploy Chinese and Western philosophies and their dialogical intersections to address tenacious problems of present-day life. By drawing on the idea of "creativity" in Whiteheadian process feminism and Chinese Yijing philosophy, Linyu Gu articulates the notion of "mutual connectivity" to assess the contemporary problematic of gender. In particular, she examines the realities of being a gendered intellectual through experiences of contemporaneity, deferral, separation, and waiting for a tomorrow that does not come and a promise that is not fulfilled. Her approach, informed by process philosophy and the thought of the Yijing, anticipates and unfolds the potential for creative balance in gender studies today. While philosophy disturbingly remains one of the least gender diverse fields in academia, our environment continues to be degraded at an alarming rate. Graham Parkes explores the ongoing devastation of the natural world from the comparative philosophical context of Laozi, Zhuangzi, and Heidegger. Parkes argues for articulating a critical stance toward technology from the resonance between these thinkers and calls for a reflective use of less damaging technologies. Martin Schonfeld's paper is likewise focused on the current ecological crisis. He examines possibilities for a civil evolution that would more adequately answer our environmental plight. Schonfeld concludes that such a step beyond the present impasse emerges from a progressive Eurasian dialogue between German "worldly wisdom" (Weltweisheit) and classical Chinese wisdom ( $z h i$ 智).

The three remaining articles illustrate additional aspects of the intersections and tensions between Chinese and Western philosophies. William Day contrasts "real knowing" (zhenzhi 真知) in Wang Yangming 王陽明 with “acknowledgment” in Stanley Cavell. Wang's unity of knowing and acting is then interpreted through Cavell's argument that knowing another's pain demands its acknowledgment. Stephen R. Palmquist investigates in his essay how Kant's critical 
philosophy and the Yijing can be analyzed as architectonic structures that encompass four perspectival "levels," each of which has an increasingly complex systematic structure. He demonstrates how each level illuminates the others and reality. Finally, I look at the question of the origins of philosophy by contrasting the unitary ontological understanding of philosophy and history in Heidegger's works with their pluralistic life-philosophical conception developed in Misch's work on the multiple origins of philosophy in China, Greece, and India.

UNIVERSITY OF MASSACHUSETTS LOWELL Lowell, Massachusetts

\section{ENDNOTES}

I would like to express my gratitude to Professor Chung-ying Cheng for warmly inviting me to organize and co-edit this supplement issue, which was originally inspired by an ISCP panel at the Pacific APA in Seattle 2012. I am also thankful to Alice Frye, Dan Lusthaus, Robin Wang, Tao Jiang, and Liu Yang for their encouragement, and in particular Linyu $\mathrm{Gu}$ for her substantial suggestions and editorial work that guided this supplemental issue into publication.

1. Georg Misch, Der Weg in die Philosophie (Leipzig: Teubner, 1926). This work was translated in a substantially altered and revised form as The Dawn of Philosophy: A Philosophical Primer (Cambridge: Harvard University Press, 1951).

2. Martin Heidegger, Beiträge zur Philosophie (Vom Ereignis), ed. Friedrich-Wilhelm von Herrmann (Frankfurt am Main: Vittorio Klostermann, 1989), 11.

3. On the affinities and divergences between Heidegger and Dilthey, see my essay "Heidegger and Dilthey: A Difference in Interpretation," in François Raffoul and Eric S. Nelson, eds., The Bloomsbury Companion to Heidegger (London: Bloomsbury Publishing, 2013), 129-134.

4. Misch, Der Weg in die Philosophie, 14; The Dawn of Philosophy, 16.

5. Misch, The Dawn of Philosophy, 44, 172. 